\title{
Investigating the Path from Supply Chain Integration to Business Performance: Evidence from a Sub-Saharan African Economy
}

\author{
Jonathan Annan ${ }^{1}$, Nathaniel Boso ${ }^{2} \&$ Dominic Essuman ${ }^{1}$ \\ ${ }^{1}$ School of Business, Kwame Nkrumah University of Science and Technology, Kumasi, Ghana \\ ${ }^{2}$ Leeds University Business School, Leeds, United Kingdom \\ Correspondence: Dominic Essuman, School of Business, Kwame Nkrumah University of Science and \\ Technology, Kumasi, Ghana. Tel: 233-024-903-1333. E-mail: kwasipowel@gmail.com
}

Received: March 4, 2016

Accepted: April 1, 2016

Online Published: May 22, 2016

doi:10.5539/ijbm.v11n6p225

URL: http://dx.doi.org/10.5539/ijbm.v11n6p225

\begin{abstract}
Following the growing concerns on the inconsistent findings in previous research and drawing on the social exchange and networking theories, this study re-examined the impact of supply chain integration (SCI) on business performance (i.e. value creation and financial performance). The study argues that the impact of SCI on financial performance is through value creation and is depended upon longevity of product life cycle. Using primary data from 79 firms in Ghana, the study finds that value creation is a short-run consequence of SCI while financial performance is a long-run outcome of SCI. Additionally, results show that the financial performance outcome of SCI is experienced more from integrative efforts than from the value creation outcome. Results further indicate that firms whose products stay relatively shorter on the market are more likely to experience lower positive impact of SCI on value creation, and thus firms' ability to become proactive, monitor, and collect market information on product performance throughout its life cycle is key for coming out with strategies that will enable them maximize product's life span so as to experience greater benefits that come with pursuing integration with other channel members.
\end{abstract}

Keywords: supply chain integration, product life cycle longevity, value creation, financial performance

\section{Introduction}

Prior supply chain (SC) research has largely focused on the antecedents and outcomes of SC practices, particularly, integration. Focusing on the link between SC integration (SCI) and business performance, researchers have drawn insights from various theories (e.g., resource-based view, social exchange theory, relational view, and networking theory) to suggest that SCI directly impacts business performance. Notwithstanding the theoretical assertions, empirical studies have over the years yielded inconsistent and inconclusive findings (see Appendix for a list of empirical studies contributing to the SCI-performance relationship). In an attempt to address the inconsistencies in the empirical literature, Fabbe-Costes and Jahre (2008) proposed a more comprehensive conceptualization of the SCI construct and studied its performance effects. Drawing on Fabbe-Costes and Jahre's conceptualization, recent studies (e.g., Boon-itt \& Wong, 2011; Gimenez et al., 2012; Huo, 2012; Huang et al., 2014; Huo et al., 2014) have studied the relationship from a contingency perspective, while others (e.g., Flynn et al., 2010; Schoenherr \& Swink, 2012) have employed configuration arguments to explain how SCI shapes business performance.

Despite these previous scholarly efforts, knowledge on why SCI impacts performance and its boundary conditions is limited (Flynn et al., 2010; Boon-itt \& Wong, 2011). This study addresses this gap by arguing that failure by previous research to specify when the effect of SCI is experienced may explain the inconsistencies in prior empirical findings. To contribute to the extant literature, therefore, this study categorizes business performance into value creation and financial performance dimensions and argues that the value creation dimension is a short-term outcome of SCI while the financial performance component is a long-term SCI outcome. In line with the social exchange and the networking theories, this study argues that (1) value creation explains why SCI impacts financial performance; and (2) longevity of product life cycle explains when SCI impacts both value creation and financial performance. We contend that SCI enables firms to create greater marketplace visibility and have the ability to coordinate operational activities to create superior customer value (Huang et al., 2014). In addition, SCI enables firms to obtain valuable resources from, and share idle resources 
with, channel partners (Yan et al., 2010; Leuschner et al., 2012) to create superior value (Johnson et al., 2008). Along this line, empirical studies have shown that SCI enhances value creation (e.g., customer service, on-time delivery), which in turn enhances financial performance (e.g., Vickery et al., 2003). Specifically, Huo's (2012) study reports that the effects of SCI (i.e. both customer and supplier integration) on financial performance is through customer-oriented performance (i.e. value creation). Thus, argument can be made that the value creation is the channel through which SCI impacts financial performance.

Additionally, in view of the dynamic and turbulent nature of contemporary business environment, a major challenge facing firms is the shortening of their product life cycles (Rao \& Goldsby, 2009), driven largely by an increasing customer demand and a rising competition (Chopra \& Meindl, 2007; Bolton \& Saxena-Iyer, 2009). In view of this, firms' ability to redesign products and respond to changes in the market requires that their SCs are built on robustness, resilience, and agility so that they can quickly reorganize systems and processes within their SCs. This, however, presents a trade-off between efficiency and effectiveness for SCs (Tang, 2006; Chopra \& Meindl, 2007; Christopher, 2011). This study addresses the trade-off challenge by identifying longevity of product life cycle as a key business environmental factor that may influence the relationship between SCI and business performance. We contend that because products have limited lifespan on the market and in view of the fact that their sales levels go through various stages (highs, slumps and stagnations), with each stage presenting different opportunities and challenges for firms (Kotler \& Keller, 2012), the performance effect of SCI is likely to vary depending upon longevity of a firm's product life cycle. The purpose of the current study is to empirically examine whether or not the effect of SCI on financial performance is channeled through customer value creation and is dependent upon longevity of product life cycles.

\section{Conceptual Background}

\subsection{Supply Chain Integration (SCI)}

Over the years, literature has undermined and been unspecific in defining and conceptualizing SCI (Mackelprang et al., 2014), and thus making the concept unclear. This has invoked numerous questions on the concept (see for e.g., Fabbe-Costes \& Jahre, 2006; Fabbe-Costes \& Jahre, 2008; Vaart \& Donk, 2008; Flynn et al., 2010; Leuschner et al., 2012) and it is believed that the incomplete definition of the concept has partly accounted for the inconsistencies in previous research findings (Flynn et al., 2010).

While some authors consider the elements or things which are integrated within the SC (see for eg., Vaart \& Donk, 2008; Gimenez et al., 2012; Moshkdanian \& Molahosseini, 2013), others focus on the directison/scope of integration (e.g., internal, supplier, \& customer - see for example, Frohlich \& Westbrook, 2001; Flynn et al., 2010; Schoenherr \& Swink, 2012). Similarly, whiles some authors (e.g., Sezen, 2008; Özdemir \& Aslan, 2011) conceive and operationalize SCI as unidimensional, others (e.g., Flynn et al., 2010; Huo, 2012) discuss it as a multidimensional construct.

In this study, we make reference to Fabbe-Costes and Jahre's (2006:2008) discussions on the various 'layers, degrees, and scopes' of integration, and define SCI as the degree to which relationships and the SC elements (e.g., SC flows - materials/products, information etc.; SC processes, activities, systems \& infrastructure, etc.) are aligned within and across an entity's SC in an effort to maximize value generated for the network.

From the perspective of the focal firm, and in line with recent approaches to understanding SCI, we employ and conceptualize the multi-dimensional nature of SCI in terms of the direction/scope of integration: internal integration, customer integration, and supplier integration (Fabbe-Costes \& Jahre, 2008; Flynn et al., 2010) and operationalize each of them in line with the key things or elements that are integrated within the focal firm and across its 'key' customers and suppliers in the network.

\subsection{Longevity of Product Life Cycle}

Product life cycle refers to the duration from when a product is introduced to the market until the time that it is viewed as a commodity by the majority of customers and its demand declines (Wong \& Ellis 2004; cited by Hashemi et al., 2013). Saying a product has a life cycle means that (1) products have limited life (on the market), (2) their sales levels go through various stages, with each stage presenting different opportunities, challenges, and problems to manufacturers and sellers, (3) their profit levels rise and fall at each of the life cycle stage; and that requires different sourcing, manufacturing, marketing, financial, and human resources strategies, in order to make the product perform well in the market (Kotler \& Keller, 2012).

Existing literature (e.g. Stonebraker \& Liao, 2006) indicates that the various stages of a product life cycle (when considered as variables) are associated with the various degrees/dimensions of SCI since at each stage, the product experiences different market issues and that requires appropriate strategies to promote the product's 
growth and sustain its survival on the market. However, there has been less emphasis on the "short-or-long" aspects of the time the product survives on the market and how it moderates the link between SCI and performance. Accordingly, this study extends knowledge by investigating into how the overall life cycle of a product moderates the relationship between SCI and value creation and financial performance. Accordingly, we use the term "longevity of product life cycle (LPLC)" in this study to mean 'how long or short' a product stays on the market before any major modification or it dies out.

\subsection{Business Performance}

Business performance outcomes of SCI has been discussed in previous literature (see Fabbe-Costes \& Jahre, 2008; Mackelprang et al., 2014) as a multi-faceted construct, and often construed as comprising of operational, marketing and financial performance criteria. Along this line, this study conceives business performance as a broader construct, comprising of value creation and financial performance outcomes.

\subsubsection{Value Creation}

As described by Kotler and Keller (2012), value is "the sum of the tangible and intangible benefits and costs" (p.10). As a key marketing concept, these authors believe that value represents a combination of quality, service, and price; and value is maximized when both quality and service increase while price is decreased or maintained. In a related sense and within the context of SCs, Chopra and Meindl's (2007) explain 'value as “...difference between what the final product is worth to the customer and the costs the supply chain incurs in filling the customer's request" (p. 5).

The conceptualization of value in this study could be identified with other terms such as 'customer facing' performance (Cadden et al., 2013), or customer-oriented performance (Huo, 2012) which often measure the service performance aspect of the SC (Droge et al., 2012). For the purposes of this study, value creation is viewed as the prime output of the SC, and thus we define it with items such as the SC's ability to offer quality products at 'reasonable' prices, deliver mostly on promises made to customers, minimize product returns/service recovery level, complaint level, and price products relative to the level of perceived benefits that customers get.

\subsubsection{Financial Performance}

Within SC and logistics studies, authors have defined and used various items to measure financial performance. For example, in evaluating the impact of SCI on performance, Flynn et al. (2010) used items such as growth in sales, return on sales, growth in return on sales, growth in profit, growth in market share, return on investment (ROI), and growth in ROI to capture financial performance, for which they conceived them as "business performance" measures. It must be noted that, the term "business performance" as used by these authors could have a much broader meaning than financial performance as used in other studies (e.g., Kim, 2009).

Notwithstanding this observation, other authors such as Huo (2012) and Huo et al. (2014) operationalized financial performance with same items used by Flynn et al. (2010). Given this lack of consensus, and for the purposes of this study, we conveniently adapted some of the commonly used items (i.e. ROI, return on assets, overall profitability, growth in profitability, and overall sales) in previous research (see Fabbe-Costes \& Jahre, 2008) to measure financial performance.

\section{Theoretical Framework and Hypothesis Development}

The theoretical framework for the study is shown in Figure 1. Our proposed model posits that financial performance is a long-run outcome of SCI while value creation is a short-run outcome of SCI and that the relationships between SCI and both outcome variables are dependent upon longevity of product life cycle. Relying on the networking theory and social exchange theory, we argue that SCI has positive impacts on both performance variables. We further argue that the positive impact of SCI on financial performance is also transmitted through value creation. 


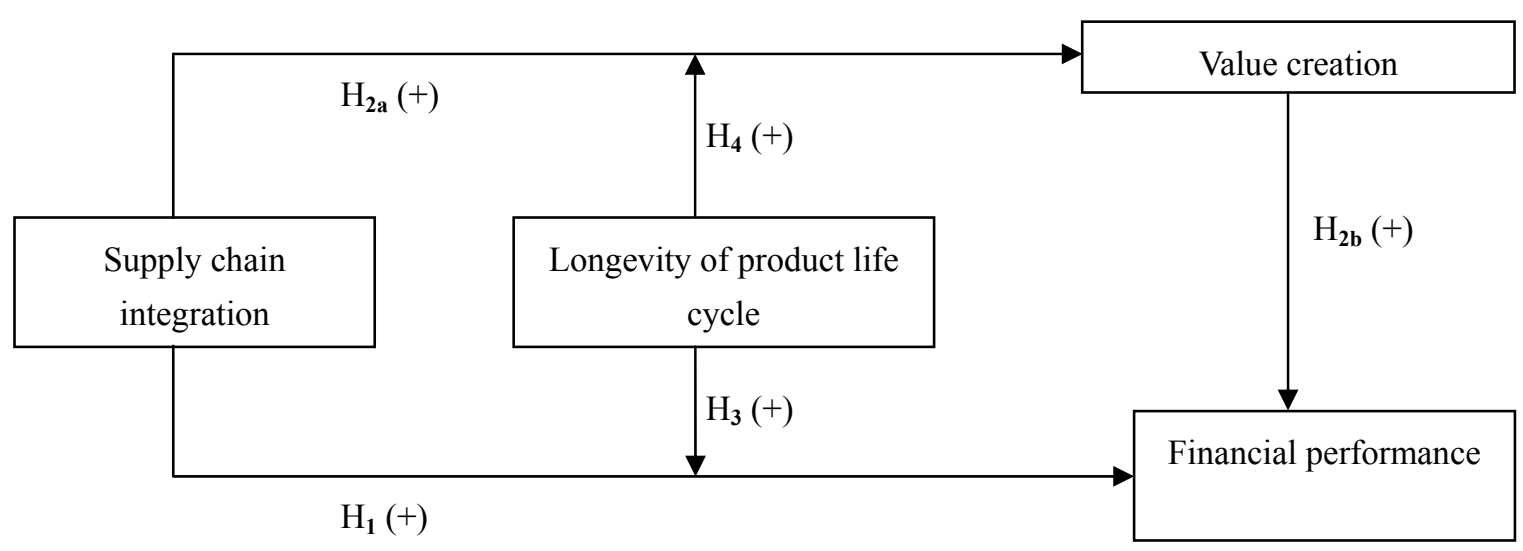

Figure 1. Proposed research model

As a key SC practice, the concept of SCI is underpinned by joint capability development and value creation through collaborative and cooperative arrangements and exchanges between/among firms (Adams et al., 2014). Formally or informally, entities within the SC from time to time identify members who they perceive as primary (Lambert, 2008) and possess some unique strengths and capabilities that are of relevance to their success and survival and focus on building alliance with them with the goal of maximizing benefits for members involved. In this sense, issues of reciprocity, mutuality, and rationality come to play when advancing for integration for a given $\mathrm{SC}$ network.

As highlighted by the networking theory, capabilities to enhance business performance could be realized when firms pursue strategic alliance (Johnson et al., 2008). In a related sense and within SCs, the social exchange theory emphasises that partnership within the SC is built on norms of mutual benefits and reciprocity (Cropanzano \& Mitchell, 2005; Näslund, 2014). It has been discussed in literature that through social exchanges and networking with other firms make it possible for firms to obtain valuable and rare resources, achieve synergy, increase economy of scope, enhance information sharing, leverage risk, minimize transaction cost or cost of operation, improve product offerings, and enhance a firm's competitiveness in an industry (Johnson et al., 2008; Yan et al., 2010; Zheng et al., 2010; Clercq et al., 2010), and through all that, firms can enhance value and financial performance.

\subsection{SCI and Financial Performance}

Drawing on the inter-firm networking theory and social exchange theory, this study argues for a positive relationship between SCI and financial performance. Conventionally, local optimization and division of labour strategies led to silo building within SCs and were wise in terms of cost cutting or efficiency. However, this was only realizable in the interim and only at the focal firm level (Christopher, 2011). The overall 'system' performance however suffered, and this manifests in the areas of inability to swiftly respond to changes in the marketplace, poor quality products, inability to meet customers' orders, high inventory cost, frequent stock outs, increased in back orders and its associated costs, high transportation cost, among others, all of which consequently derail financial outcomes of firms.

It should be noted that, most financial performance indicators (such as growth in profitability, ROI, ROA) as employed in SC studies are relatively long-term business performance measures, and to achieve these requires sustained coordinated activities and processes and long-term collaboration between/among members within the SC, which SCI enables firms to realise (Boon-itt \& Wong 2011; Flynn et al., 2011). In light of this, we hypothesize that:

\section{$H_{1}: S C I$ is positively related to financial performance}

\subsection{The Effect of SCI on Financial Performance via Value Creation}

The positive impact of SCI on value creation and also value creation as a source capability for enhancing financial outcomes are well established in literature. It is noted that value can be added to either products or services through integrative efforts by channel members (Westbrook, 2002; Vickery et al., 2003; Done, 2011). $\mathrm{SCI}$ ensures a more accurate forecast of demand and proper planning. It is noted that, failing to forecast and plan accordingly is a doom for all operations within the SC since it is the customer's order/demand that triggers all 
processes and functions within the SC (Chopra \& Meindl, 2007).

Through SCI, firms are able to have better knowledge of the customer's needs, have much visibility and coordinate activities seamlessly and deliver on the customer's order better than it would have when there existed fragmentations within entities and or across the network (Boon-itt \& Wong, 2011; Huang et al., 2014). In this regard, firms who better understand the market needs and have the right information on demand would be able to provide (customized) products and services that actually meet the needs of the market at a relatively lower operational cost (resulting from SC visibility, efficient inventory levels, reduction in back order cost, etc.).

In so doing, firms would be able to provide higher quality products and service levels at a relatively lower prices and thereby end up maximizing value for the customer. In this regard and drawing on previous literature claims that value creation is the main objective of SCs (Chopra \& Meindl, 2007; Christopher, 2011), it can be said logically that the main output of SCI initiatives or implementation is value creation. That is, firms who pursue SCI are, first of all, expected to experience improved value for their customers.

It should be expected that, when value to the customer is enhanced, firms would stand a better chance of retaining existing customers, increase market share, and consequently increase sales volume as well as profit levels. Studies by authors such as Vickery et al. (2003) and Huo (2012) report that value creation activities such as customer service, short and consistent lead time, on-time delivery, flexibility, and responsiveness with SCs improve financial outcomes. Accordingly, we hypothesize that:

$H_{2 a-b}$ : Value creation positively mediates the effect of SCI on financial performance

\subsection{The Moderating Role of Product Life Cycle}

Over the years, the life cycle of most products have been shrinking (Croxton et al., 2001; Chopra \& Meindl 2007; Bolton \& Saxena-Iyer, 2009). Typical products like motor car whose life was measured in several years is now measured in few years. At any point in a product's life, the needs of customers and demand characteristics change. This also affect supply requirements needed to produce products that the market requires. Therefore, SCs have to engage in much reengineering frequently in order to build and introduce new products (i.e. modifications to existing products, service delivery systems, programmes, markets, etc.) and adopt measures that help in achieving competitive advantage and strategic fit (Aitken et al., 2003; Chopra \& Meindl, 2007; Kotler \& Keller, 2012).

As most markets experience now, customers are becoming increasingly demanding, and competition and or product substitutes tend to be on the rise. As noticed by Chopra and Meindl (2007), the shortening life cycle of products makes it challenging for achieving strategic fit in SCs, as from time to time, managers would have to constantly adapt, reorganise, produce, and deliver "new" products that the market asks for. It should be mentioned that at the conceptual stage, a firm would find it difficult to accurately predict the patterns that its product will go through, from the introduction stage through to the growth stage to maturity stage till it declines (Aitken et al., 2003).

As such, when a product life cycle is long enough, the operations within the SC tends to be more stable as demand becomes predictable. In effect, existing relationships, processes and structures would not suffer much. Hence, the SC can have enough time to plan, coordinate efforts and processes, and deliver on customers' requirements better. Based these, we argue that:

$H_{3}$ : The positive effect of SCI on financial performance is strengthened (i.e. becomes more positive) when product life cycle is longer.

$H_{4}$ : The positive effect of SCI on value creation is strengthened (i.e. becomes more positive) when product life cycle is longer.

\section{Methodology and Results}

\subsection{Sampling and Data Collection}

In testing our proposed research model, we collected data from firms operating in the Ashanti Region of Ghana. The Ashanti Region was chosen for the study due to its key role in economic activities in the country and also it being the commercial and industrial hub linking the northen and sourthen Ghana as well as the surrouonding landlocked countries. Major commericial and industrial activities in this part of the country is located within the Kumasi Metropolitan area and large proportion of the population are engaged in sales and production work (Ghana.gov.gh, n.d.).

The nature of concepts being investigated required narrowing down the broad sample into a more homogenous group that could provide data on all the constructs. For example, firms considered were to be operating through 
(at least, some form of) functional units (for the purposes of assessing internal integration). That is, 'one-man-does-all' firms were excluded. Similarly, the focal firm to be considered in the study was to be one whose product life cycle could clearly be identified. Hence, intermediary firms were not included in the study since products mostly 'pass through' their hands. Specifically, two sample groups: manufacturing and service firms; were considered. The manufacturing firms operated in the following sub-industries: Food \& Beverages, Pharmaceuticals \& Chemicals, Agri-business, Toiletries \& Cosmetics, and Rubber, Plastics \& related. Service firms considered were limited to those in the hospitality industry and the financial industry.

In the actual field study, we relied on the online database of Yellow Pages Ghana and Association of Ghana Industries to retrieve contacts (e.g. emails, location addresses) of the firms that fit into our study. For firms that we were able to obtain their email addresses, emails were sent to key informants explaining the need for the study and seeking their consent. In all, 27 emails were sent. After 2 weeks, we got 1 firm responding. This response showed that this strategy would not work within this research context. Hence, we followed two other strategies. In this first case, we approached as many firms as we could and left behind an envelope which contained a letter of introduction and a questionnaire. The letter specified the positions of individuals who were capable of responding to the questionnaire. For firms that we could not contact directly, we spoke with the Executive and Part-time MBA students of KNUST School of Business (Kumasi) and some of these students helped us in reaching out to the remaining firms. Forty-three contacts were made and 36 questionnaires were collected within the time frame for the field study. In the other case, 74 firms were reached. However, 47 questionnaires were returned after 4 weeks when the questionnaires were delivered. In all, 117 questionnaires were distributed and at the end of the field study, 83 were retrieved. A preliminary check on the questionnaires resulted in retaining 79 for the purposes of the study as four questionnaires had severe missing values.

In line with previous studies (e.g., Flynn et al., 2010; Gimenez et al., 2012), for each firm contacted, a key informant was identified and asked to respond to the study. The most targeted informants in previous research have been individuals who hold senior positions such as SC/logistics manager/officer, CEO/president/vice president/, Managing director, or other individuals perceived to have adequate knowledge about the company's internal and external operating environment (e.g., operations manager). In line with previous research, therefore, similar individuals became our targets for the study. Respectively, $15.4 \%, 41.0 \%, 17.9 \%$, and $25.6 \%$ of the responses were collected from these informants. Also, data was collected on the number of years the informants have held their current positions in their respective organisations revealed that an average informant has had 3.73 years ( $\min =1 ; \max =15 ; \mathrm{SD}=2.502$ ) experience in his/her current position.

Further, using a scale of 1 (strongly disagree) to 7 (strongly agree), the respondents' competence were assessed in terms of knowledge adequacy on the issues (Mean=5.92; $\mathrm{SD}=1.083$ ), understanding of statement on the data collection instrument (Mean=6.06; $\mathrm{SD}=.925$ ), confidence in responses provided (Mean=6.16, $\mathrm{SD}=.940$ ), and assurance that the responses provided represented the realities in the firm (Mean=6.13, $\mathrm{SD}=1.030)$. These scores obtained gave a sufficient confidence that informants were competent enough to provide responses for the study. Data on the firms show that the average firm contacted for the study has been in the industry for 15 years ( $\mathrm{min}=2$; $\max =104 ; \mathrm{SD}=18.5)$, has an average of 130 full-time employees $(\min =4 ; \max =1200 ; \mathrm{SD}=196)$, and operates an average of 5 functional areas $(\min =2 ; \max =12 ; \mathrm{SD}=2)$. In all, 22 out of the 79 firms have dedicated SC/logistics functional units.

\subsection{Instrument Development and Measures}

From relevant literature, we adapted items to measure most of the constructs. SCI was conceived as a three dimensional constructs in terms of direction/scope of integration: internal integration (II), customer integration (II), and supplier integration (SI). Each was operationalized with seven items and were all measured with a 7 point scale ranging from $1=$ "not at all" to $7=$ "to a largest to extent".

The items for SI and CI were adapted from Flynn et al. (2010), Miguel and Brito (2011), Danese and Romano (2011), and Seo et al. (2014) while most those for II were adapted from Huo (2012). Unlike previous researchers who mostly limited the wordings of the items measuring II to (cross) functional integration, the construction of some of our items considered integration at all managerial levels.

In measuring value creation, a 7-point scale ranging from $1=$ "strongly disagree" to $7=$ "strongly agree" was used. The items for measuring value creation were adapted from Kotler and Keller's (2012) definition of value creation and also from Cadden et al's (2013) study. In the case of financial performance, the items were measured using a 7-point scale, ranging from 1= "very dissatisfied" to 7= "very satisfied" and were adapted from Kim (2009) and Huo et al. (2014). Five items each were used to measure value creation and financial performance. 
In the case of longevity of product life cycle (LPLC), perceiving the potential difficulty in measuring the exact (quantitative) life cycle of a firm's product and also the lack of literature on how to operationalize this construct, we developed our own items to measure it. In all we came out with five items. A 7 point scale (where $1=$ "strongly disagree" to $7=$ "strongly agree) was employed.

As indicated earlier on, the questionnaire also contained the following items: business experience (number of years in the industry), firm size (number of full-time employees), firm-type ( $0=$ Service; $1=$ Manufacturing), and whether or not a firm has a designated SC/Logistics department/unit $(0=\mathrm{No} ; 1=$ Yes $)$, which were all controlled for in our analysis.

\subsection{Reliability and Validity of Measures}

In assessing the reliability of the measures, Cronbach alpha was used. The results of this test as shown in Table 1 reveal all alpha values greater than the recommended threshold of .70 (Bagozzi \& Yi, 2012) and thus suggests that each scale employed had good internal consistency (Field, 2009). Further, confirmatory factory analysis (CFA) was conducted in LISREL 8.8 by relying on maximum likelihood estimation method. Covariance matrix was used as input data. After necessary modifications, a satisfactory model fit to data was obtained: $\chi^{2}$ (degree of freedom $[\mathrm{df}]=298.59(237)$; normed $\mathrm{Chi}$ square $\left[\chi^{2} / \mathrm{df}\right]=1.260$; root mean square error of approximation $[$ RMSEA $]=.058$; non-normed fit index $[\mathrm{NNFI}]=.963$; comparative fit index $[\mathrm{CFI}]=.968$; standardized root mean square residual $[$ SRMR] $=.079$ (Bagozzi \& Yi, 2012; Hair et al., 2014). Table 1 shows the list of the retained items, their respective standardized loadings, $t$-values, and the composite reliability (CR) and average variance extracted (AVE) values. All factor loadings were significant at $1 \%$. The positive and significant loadings confirm convergent validity of the measures (Boso et al., 2013). The respective values of CR and AVE obtained for each construct were satisfactory; given a minimum cut off criteria of .60 and .50 respectively. All AVEs obtained were also larger than the shared variances between constructs signifying satisfactory discriminant validity (Fornell \& Larcker, 1981).

Table 1 . Reliability and validity results

\begin{tabular}{|c|c|}
\hline Constructs/Measures & Loadings (t-value) \\
\hline \multicolumn{2}{|l|}{ Customer integration $(C R=.882 ; A V E=.654 ; C A=.890)$} \\
\hline You and your key customers collaborate in planning and making decisions & .719 (fixed) \\
\hline You and your key customers have common interest and goals & $.924(7.66)$ \\
\hline You and your key customers provide supports and assistance to each other & $.807(6.87)$ \\
\hline Your business processes \& systems are aligned with customers' needs & $.770(6.56)$ \\
\hline \multicolumn{2}{|l|}{ Internal integration $(C R=.841 ; A V E=.642 ; C A=.871)$} \\
\hline This firm makes use of cross-functional teams and collaboration & .837 (fixed) \\
\hline There is visibility in processes and operations across all levels $\&$ unit areas & $.877(8.63)$ \\
\hline Systems and controls are aligned across all levels \& unit areas & $.675(6.35)$ \\
\hline \multicolumn{2}{|l|}{ Supplier integration $(C R=.965 ; A V E=.672 ; C A=.944)$} \\
\hline Key suppliers are involved in planning and decision making & .858 (fixed) \\
\hline Key suppliers are involved in idea generation \& product/service design & $.849(9.79)$ \\
\hline Key suppliers have visibility in your operations (e.g. inventory level) & $.868(10.19)$ \\
\hline You engage key suppliers in process improvement initiatives & $.775(8.40)$ \\
\hline You and your key suppliers share business information in real time & $.783(8.55)$ \\
\hline You and your key suppliers have aligned processes \& systems & $.844(9.69)$ \\
\hline You and your key suppliers have long-term alliances and common interest & $.753(8.02)$ \\
\hline \multicolumn{2}{|l|}{ Longevity of product life cycle $(C R=.893 ; A V E=.676 ; C A=.894)$} \\
\hline Most product/service offerings die out earlier than expected/anticipated ${ }^{*}$ & .761 (fixed) \\
\hline Most new products/services launched do not get the expected market acceptance ${ }^{*}$ & $.828(7.60)$ \\
\hline Most products/services usually do not stay on the market for long ${ }^{*}$ & $.902(8.32)$ \\
\hline Most products/services introduced record poor sales levels ${ }^{*}$ & $.791(7.22)$ \\
\hline \multicolumn{2}{|l|}{ Value creation $(C R=.761 ; A V E=.520 ; C A=.753)$} \\
\hline This firm offers high quality products at reasonable prices & .679 (fixed) \\
\hline This firm mostly delivers on its promises to customers & $.851(5.26)$ \\
\hline Your products are priced relative to the level of perceived benefits that customers get & $.611(4.57)$ \\
\hline \multicolumn{2}{|l|}{ Financial performance $(C R=.850 ; A V E=.656 ; C A=.836)$} \\
\hline Overall profitability & .898 (fixed) \\
\hline Growth in profitability & $.736(7.39)$ \\
\hline Overall sales & $.787(8.09)$ \\
\hline
\end{tabular}

Notes. ${ }^{*}=$ items were reverse coded, $\mathrm{CR}=$ composite reliability, $\mathrm{AVE}=$ average variance extracted, $\mathrm{CA}=\mathrm{Cronbach}$ alpha. 


\subsection{Common Method Bias Test}

Given that one informant from each case firm provided all responses for the study, it became necessary to examine the potential problem of common method bias (CMB) in the study (Podsakoff et al., 2003). By employing method-only model in LISREL, all the retained items after the CFA were set to load on one latent factor. This analysis yielded the following results: $\chi^{2}(\mathrm{df})=893.95(252) ; \chi^{2} / \mathrm{df}=3.547$; RMSEA $=.181$; NNFI=.841; $\mathrm{CFI}=.855$; $\mathrm{SRMR}=.124$. These results generally indicate poor fit to data which indicates that $\mathrm{CMB}$ does not sufficiently describe the data collected and hence a conclusion was reached that CMB is not a major concern for the study.

\subsection{Structural Model Estimation and Results}

With reference to our proposed model and for parsimonious reasons, the three dimensions of SCI (CI, II, \& SI) were treated as a single indicant variable. Relying on the retained items, composite variables were created for each sub-construct of SCI using summated scales (Hair et al., 2014). With regard to the moderating effects, an interaction term for the proposed paths was created. Given longevity of product life cycle (LPLC) as the moderating variable, a single indicant variable was created by following the residual centring procedures. The residual centring approach was used to attenuate for the potential multicollinearity problems (Tabachnick \& Fidell, 2013). Correlational analysis was first of all used to examine the bivariate relationships between the variables. The results produced as well as the descriptive results are shown in Table 2.

Table 2. Inter-variable correlations and descriptive results

\begin{tabular}{|c|c|c|c|c|c|c|c|c|c|c|}
\hline \multicolumn{2}{|c|}{ Variables } & 1 & 2 & 3 & 4 & 5 & 6 & 7 & 8 & 9 \\
\hline 1 & Firm type $^{\mathrm{d}}$ & & & & & & & & & \\
\hline 2 & SC unit ${ }^{d}$ & $.223^{*}$ & & & & & & & & \\
\hline 3 & Firm size $^{o}$ & 0.172 & $.383^{* *}$ & & & & & & & \\
\hline 4 & Business experience $^{\circ}$ & $.211^{*}$ & $.377^{* *}$ & $.723^{* *}$ & & & & & & \\
\hline 5 & $\mathrm{SCI}$ & $.321^{* *}$ & $.293^{* *}$ & $.339^{* *}$ & $.339^{* *}$ & & & & & \\
\hline 6 & LPLC & $.350^{* *}$ & $.220^{*}$ & .16 & .146 & $.651^{* *}$ & & & & \\
\hline 7 & SCI $x$ LPLC & -0.045 & 0.102 & -.058 & .115 & .000 & .000 & & & \\
\hline 8 & Value creation & $.196^{*}$ & $.217^{*}$ & .13 & $.394^{* *}$ & $.442^{* *}$ & $.211^{*}$ & $.349^{* *}$ & & \\
\hline 9 & Financial performance & $.317^{* *}$ & $.403^{* *}$ & $.399^{* *}$ & $.484^{* *}$ & $.641^{* *}$ & $.377^{* *}$ & .100 & $.470^{* *}$ & - \\
\hline \multicolumn{2}{|c|}{ Mean } & & & & & 4.7 & 5.23 & .00 & 4.88 & 4.71 \\
\hline \multicolumn{2}{|c|}{ Standard deviation } & & & & & .948 & 1.206 & 1.115 & .964 & 1.055 \\
\hline
\end{tabular}

In estimating the proposed model, hierarchical regression analysis was used. Given the two outcome variables in the model, two analyses were run. For analysis one, value creation was the dependent variable while the second analysis had financial performance as the dependent variable. In each case, three hierarchal models were run. Model one in each case was predicted by the four control variables. The second and the third in each case respectively were predicted by the main effects variables and the interaction term. The results obtained are shown in Table 3. The evaluation of the study's propositions was based on selecting a superior model, that is, a model that resulted in a significant change in $\mathrm{R}^{2}$ over the previous one. In this sense, Model 3 (for analysis one) and Model 2 (for analysis two) were selected for the evaluatioin of the hypotheses.

In reference to the results in Table 3, the study's hypotheses were evaluated as follows. $\mathrm{H}_{1}$ argues that $\mathrm{SCI}$ is positively related to financial performance. The study's results $(\beta=.438 ; \mathrm{t}=3.722)$ provides support for this hypothesis. Also, $\mathrm{H}_{2 \mathrm{a}-\mathrm{b}}$ argues that value creation positively mediates the effect of SCI on financial performance. The results of study: $\mathrm{SCI} \rightarrow$ value creation $(\beta=.404 ; \mathrm{t}=3.181)$ and value creation $\rightarrow$ financial performance $(\beta=.164 ; \mathrm{t}=1.664)$; partially support this hypothesis, given that the path from SCI to financial performance is also statistically significant. Further, the study advanced an argument that longevity of product life cycle moderates the links between SCI and financial performance $\left(\mathrm{H}_{3}\right)$ and value creation $\left(\mathrm{H}_{4}\right)$. While findings do not provide support for $\mathrm{H} 3$, the results provide support for $\mathrm{H}_{4}(\beta=.261 ; \mathrm{t}=2.719)$. 
Table 3. OLS regression analysis results

\begin{tabular}{|c|c|c|c|c|c|c|}
\hline \multirow{3}{*}{ VARIABLE } & \multicolumn{6}{|c|}{ Standardised estimates } \\
\hline & \multicolumn{3}{|l|}{ Value creation } & \multicolumn{3}{|c|}{ Financial performance } \\
\hline & Model 1 & Model 2 & Model 3 & Model 4 & Model 5 & Model 6 \\
\hline \multicolumn{7}{|l|}{ CONTROLS: } \\
\hline Firm type $^{d}$ & $.110(1.032)$ & $.044(.410)$ & $.065(.638)$ & $.190(1.921)^{*}$ & $.078(.876)$ & $.079(.880)$ \\
\hline SC unit ${ }^{d}$ & $.114(1.009)$ & $.072(.664)$ & $.040(.386)$ & $.228(2.163)^{*}$ & $.154(1.685)^{*}$ & $.152(1.653)^{*}$ \\
\hline Firm size & $-.336(-2.253)^{* *}$ & $-.383\left(-2.703^{* *}\right.$ & $-.307(-2.215)^{*}$ & $.017(.126)$ & $.016(.132)$ & $.018(.146)$ \\
\hline Business experience & $.561(3.761)^{* *}$ & $.511(3.600)^{* *}$ & $.435(3.129)^{* *}$ & $.349(2.518)^{* *}$ & $.203(1.572)$ & $.202(1.546)$ \\
\hline \multicolumn{7}{|l|}{ HYPOTHESISED: } \\
\hline \multicolumn{7}{|l|}{ Main effects } \\
\hline SCI & & $.398(3.006)^{* *}$ & $.404(3.181)^{* *}$ & & $.438(3.722)^{* *}$ & $.440(3.686)^{* *}$ \\
\hline LPLC & & $-.089(-.688)$ & $-.094(-.758)$ & & $-.030(-.278)$ & $-.031(-.282)$ \\
\hline VALUE & & & & & $.164(1.664)^{*}$ & $.160(1.528)$ \\
\hline \multicolumn{7}{|l|}{ Interaction effect } \\
\hline SCI*PLC & & & $.261(2.719)^{* *}$ & & & $.013(.144)$ \\
\hline \multicolumn{7}{|l|}{ FIT INDICES: } \\
\hline $\mathrm{R}^{2}$ & .220 & .321 & .385 & .327 & .530 & .531 \\
\hline$\Delta \mathrm{R}^{2}$ & & .101 & .064 & & .203 & .001 \\
\hline Adj. $R^{2}$ & .178 & .264 & .324 & .291 & .484 & .477 \\
\hline F-statistics & $5.219^{ \pm}$ & $5.345^{ \pm}$ & $7.395^{ \pm}$ & $9.005^{ \pm}$ & $10.231^{ \pm}$ & .021 \\
\hline $\mathrm{df}$ & 74 & 72 & 71 & 74 & 71 & 70 \\
\hline
\end{tabular}

Notes. t-values are in the parenthesis; ${ }^{*} \mathrm{p}<.05$ (1-tailed); ${ }^{* *} \mathrm{p}<.01$ (1-tailed); ${ }^{ \pm}$model sig at $1 \%$; hypothesized paths were evaluated at $5 \%$; critical valu $=1.645$ (1-tailed).

\section{Discussions and Implications}

Generally, the study's results indicate that higher levels SCI integration are associated with higher levels of business performance, in terms of value creation and financial performance. These findings are in line with theories (i.e. networking theory and social exchange theory) that underpin this study and also reinforce previous research findings (e.g., Frohlich \& Westbrook, 2001; Flynn et al., 2010; Wong et al., 2011; Huo, 2012; Prajogo \& Olhager, 2012). The study's findings buttress that the role of SCI in enhancing business performance cannot be undermined in today's competitive environment. As competition is shifting from among firms to among SCs (Lambert, 2008), it is only when firms within a given network integrate (i.e. collaborate, cooperate, coordinate and streamline their processes and activities) that they can better understand their market well, collect and share information in real-time, and swiftly produce products and services that address the needs of the market at a relatively lower cost. As firms deepen their relationships with other members in the network and share mutual interests and goals, they are more likely to build trust and get the necessary commitment from other members. The study's findings also suggest that firms could obtain unique resources and capabilities to drive business performance when they pursue integration.

At one breadth, literature notes that through integration (e.g., networking and alliance), support and assistance can be obtained from other channel members (Johnson et al., 2008; Yan et al. 2010) and enable a firm to compete favourably, produce and offer products and services that offer greater value for customers, sell more and end up enhancing financial outcomes such as sales and profitability. At another breadth, through integration, firms would be more able to gain focus and build core competencies and capabilities in the area of information, knowledge, expertise, and experience, which when pooled together and shared, would present a greater synergistic edge for a network that dwells on integration than those networks that are inwardly focused.

The findings further reinforce that when firms seek to optimize processes and operations solely at the organisational level, such initiative would become detrimental to performance. And thus, firms are cautioned that when integration is absent in their SCs, system failure is more likely to be recorded, which could manifest in (1) firms' inability to improve customer experience for their products, (2) rising costs and wastes (e.g. high inventory levels, stock-out costs, transportation cost), (3) poor product quality, and (4) reduced sales and profit levels.

Notwithstanding the above, the study specifically finds that the association between SCI and financial performance $(\beta=.438)$ is relatively stronger than the association between SCI and value creation $(\beta=.404)$. This 
finding somehow seems not surprising. Generally, it is well noted that implementing SCI could require substantial investments in both financial (e.g., investment in information technology, supporting and developing smaller firms in the network) and non-financial (e.g., time, commitment etc.) resources (Awasthi \& Gryzbowska, 2014). Hence, the short-run or the immediate positive impact of SCI on business performance, that is, value creation (as in, minimizing cost of producing and delivery products, offering higher quality products/services at a relatively lower prices, adding on more products enhancements etc.), should be expected in some cases to be lower, compared to its long term impact, that is, financial outcomes. In the long-run, firms in the SCs who pursue SCI would have obtained mastery, and become more effective and built greater capabilities and hence would be likely to benefit more from integration in the area of growth in sales and profitability, return on investment and return on assets.

In a related result, the study finds that, the direct effect of SCI on financial performance (unstandardized $\beta=.428$ ) is higher than its indirect effect through value creation (product of the unstandardized $\beta$ values of the indirect path $\left.=.434^{*} .181=.079\right)$. And thus, this finding points out that not all the positive effect of SCI on value creation may necessarily translate into enhancement of financial outcomes. This finding seem to be in contrary with the results from Huo's (2012) study. The relatively weaker association between value creation and financial performance could be explained from a competition point of view. As commonly prevails in most industries, there is high competitive intensity and firms aggressively monitor the actions of other competing firms' processes, products and service offerings, and come out with innovative processes and products which help them offer equivalent value for customers. Hence, the likelihood of value creation (resulting from SCI) leading to increases in financial outcomes such as sales and profitability may be less likely to occur since the customer could hardly differentiate and make purchase decisions by the uniqueness of a firm's value propositions. In such operating environments, keeping products on the market through advertising alone could eat away profitability.

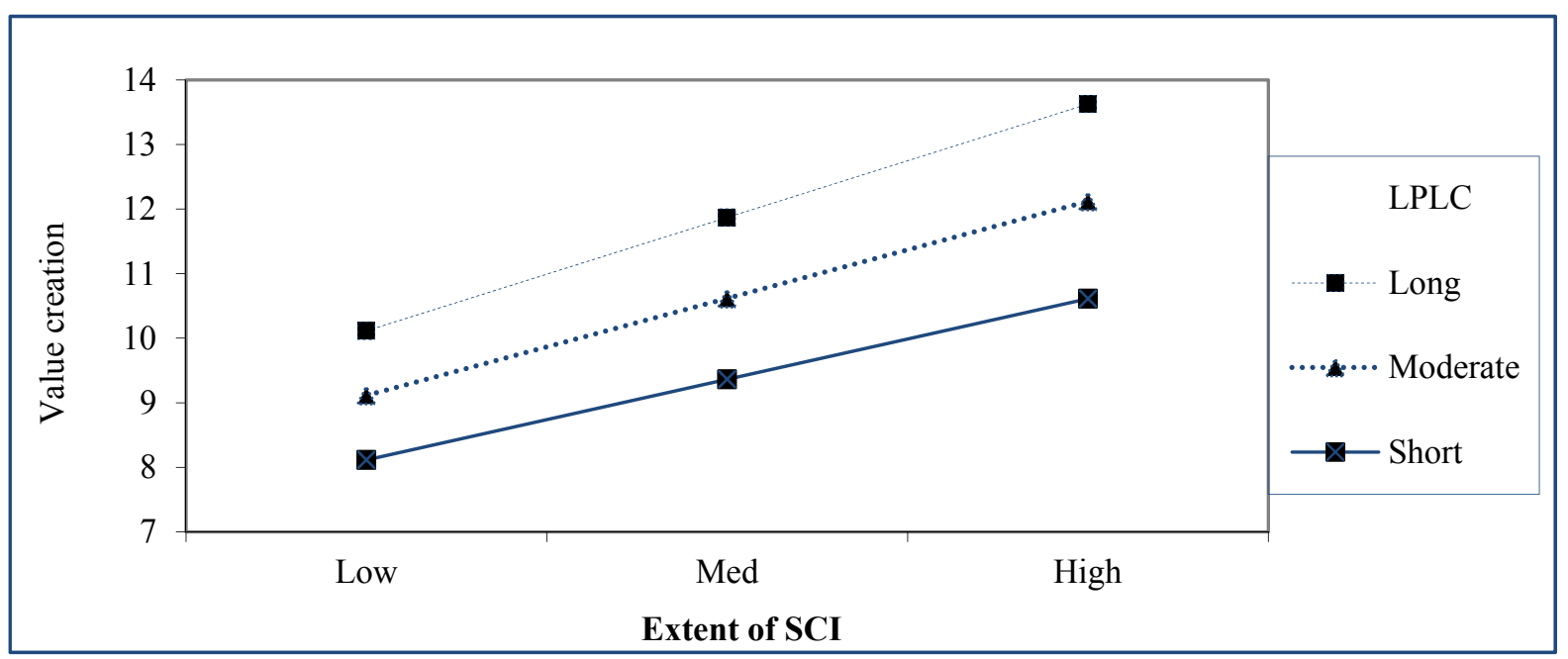

Figure 2. The moderation effect of LPLC on the link between SCI and VALUE

Lastly, the study finds statistical support for our claim that the relationship between SCI and value creation is moderated by longevity of product life cycle. The study finds evidence that when products stay relatively longer on the market, the positive effect of SCI on value creation is strengthened. This is demonstrated in Figure 2. However, there was no statistically significant support for the moderating role of longevity of product life cycle in the link between SCI and financial performance.

Generally, the life cycle of most products are shortening. However, due to the degree of variability in competitive pressure, proliferation of substitute products and the extent to which customer and market needs vary across industries, some firms'/industries' products should be expected to relatively stay shorter or longer on the market. For a more turbulent market which makes the life cycle of products uncertain, firms/SCs could mitigate any potential or consequential negative effects on their value adding activities by becoming proactive and constantly monitoring the market and relying on the voice-of-the-customer (i.e. making operations decisions based on actual information received from the customer) in order to promote the life span of their products. Without this, it should be expected that any positive effects of integration on value will be weakened when the market and demand needs constantly change and competition increases which make their products die out 
quicker on the market than anticipated.

\section{Conclusion, Limitations and Suggestions for Future Research}

The results obtained from the study suggest that winning the 'war' or 'surviving' in today's market requires firms in a given SC to build capabilities and competencies not only through internal resources that they possess or internal performance-improvement practices but also via building strategic alliances and network ties, aligning processes, coordinating activities, and engaging in social exchanges.

The study's results reinforced extant empirical research that found that SCI enables firms to enhance business performance. Notwithstanding this, the study also brings to light the potential role of product life cycle in either strengthening or weakening the positive effect of SCI on business performance. Specifically, we found empirical support to our claim that firms whose products stay relatively longer on the market are more likely to experience greater performance in terms of value creation than those whose products stay shorter on the market and therefore proactiveness, constant monitoring, and gathering information on the performance of products on the market throughout their life cycles are required of firms in order to promote the longevity of products, sustain integrative efforts, and enhance value creation.

Although this study presents interesting findings and sheds new lights from data collected from the study's context, it cannot be absolved from certain limitations. The first limitation of the study has to do with the sample size relied on in estimating the study's proposed model. Relatively, most empirical studies reviewed relied on greater sample size which was more reliable in identifying significant relationships among variables. In this study, the hypothesized moderating effect of product life cycle on the link between SCI and financial performance was non-significant (although positive as specified), which might have been as a result of the sample size used in the study. It is therefore recommended that this proposed path be re-examine by future researchers by employing larger sample size in their studies.

In addition, although arguments were made in the study with reference to the increasing competition from new entrants and substitute products as well as the increasingly demanding nature of customers as potential causes of the shortening life cycle of products, no empirical data were collected to substantiate these propositions. Hence, further studies should focus on verifying if those factors are significant antecedents of the shortening life cycle of products within SCs.

Also, in this study, we were mainly interested in verifying theory, as such no emphasis was placed on examining factors that restrain SCI efforts. It must be noted that, as a developing economy, firms in Ghana are constantly faced with threats and market shake-ups in their respective operating environments which could make it difficult for some to be successful in pursuing SCI. Although existing literature lists many potential barriers to SCI, we perceive that such barriers and the extent to which they are present in firms and SCs and thus affect SCI may vary across contextual grounds. For example, the inter-variable correlational results (Table 2) indicate that manufacturing firms, firms with dedicated SC units, larger in size, and have longer industry experience do better in pursuing SCI. And thus it can be said that these factors could be antecedents of SCI and or serve as contingent factors in the link between SCI and business performance (Mackelprang et al., 2014). However this present study did not focus on investigating into these propositions. Hence, further studies can be undertaken along this direction.

\section{References}

Adams, F. G., Richey Jr., R. G., Autry, C. W., Morgan, T. R., \& Babler, C. B. (2014). Supply chain collaboration, integration, and relational technology: How complex operant resources increase performance outcomes. Journal of Business Logistics, 35(4), 299-317. http://dx.doi.org/10.1111/jbl.12074

Aitken, J., Childerhouse, P., \& Towill, D. (2003). The impact of product life cycle on supply chain strategy. Int. J. Production Economics, 85, 27-140. http://dx.doi.org/10.1016/S0925-5273(03)00105-1

Awasthi, A., \& Grzybowska, K. (2014). Barriers of the supply chain integration process. Logistics Operations, Supply Chain Management and Sustainability. http://dx.doi.org/10.1007/978-3-319-07287-6

Bagozzi, P. R., \& Yi, Y. (2012). Specification, evaluation, and interpretation of structural equation models. Academy of Marketing Science, 40(1), 8-34. http://dx.doi.org/10.1007/s11747-011-0278-x

Bolton, R., \& Saxena-Iyer, S. (2009). Interactive services: A framework, synthesis and research directions. Journal of Interactive Marketing, 23(1), 91-104. http://dx.doi.org/10.1016/j.intmar.2008.11.002

Boon-itt, S., \& Wong, Y. C. (2011). The moderating effects of technological and demand uncertainties on the 
relationship between supply chain integration and customer delivery performance. International Journal of Physical Distribution \& Logistics Management, 41(3), 253-276. http://dx.doi.org/10.1108/09600031111123787

Boso, N., Story, V. M., \& Cadogan, J. W. (2013). Entrepreneurial orientation, market orientation, network ties, and performance: Study of entrepreneurial firms in a developing economy. Journal of Business Venturing, (28), 78-727. http://dx.doi.org/10.1016/j.jbusvent.2013.04.001

Cadden, T., Marshall, D., Cao, G., \& Cadden, T. (2013). Opposites attract: Organisational culture and supply chain performance. Supply Chain Management: An International Journal, 18(1), 86-103. http://dx.doi.org/10.1108/13598541311293203

Carter, P. L., Monczka, R. M., Ragatz, G. L., \& Jennings, P. L. (2009). Supply chain integration: Challenges and good practices. CAPS: Center for Strategic Supply Research, 1-104.

Chopra, S., \& Meindl, P. (2007). Supply chain management, strategy, planning \& operation (3rd ed.). New Jersey: Pearson Education.

Christopher, M. (2011). Logistics and supply chain management strategies (4th ed.). London: FT Prentice Hall

Clercq, D. D., Dimov, D., \& Tek, N. (2010). The moderating impact of internal social exchange processes on the entrepreneurial orientation-performance relationship. Journal of Business Venturing, 25(1), 87-103. http://dx.doi.org/10.1016/j.jbusvent.2009.01.004

Cropanzano, R., \& Mitchell, M. S. (2005). Social exchange theory: An interdisciplinary review. Journal of Management, 31(6), 529-621. http://dx.doi.org/10.1177/0149206305279602

Croxton, K. L., García-Dastugue, S. J., Lambert, D. M., \& Rogers, D. S. (2001). The supply chain management processes. The International Journal of Logistics Management, 12(2), 13-36. http://dx.doi.org/10.1108/09574090110806271.

Danese, P., \& Romano, P. (2011). Supply chain integration and efficiency performance: A study on the interactions between customer and supplier integration. Supply Chain Management: An International Journal, 16(4), 220-230. http://doi.org/10.1108/13598541111139044

Done, A. (2011). Integrating Supply chains: an investigation of collaborative integrating supply chains: an investigation of collaborative. Working Paper WP-896, (3). Spain: IESE Business School.

Droge, C., Vickery, K. S., \& Jacobs, A. M. (2012). Does supply chain integration mediate the relationships between product/process strategy and service performance? An empirical study. Int. J. Production Economics, 137(2), 250-262. http://dx.doi.org//10.1016/j.ijpe.2012.02.005

Fabbe-Costes, N., \& Jahre, M. (2006). Logistics integration and disintegration - in search of a framework. In International Conference on Information Systems, Logistics and Supply Chain (ILS'06) (pp. 841-850). Mons, Belgium: FUCAM Edition.

Fabbe-Costes, N., \& Jahre, M. (2008). Supply Chain integration and performance: A review of the evidence. The $\begin{array}{lllll}\text { International Journal of Logistics } & \text { Management, }\end{array}$ http://dx.doi.org/10.1108/09574090810895933

Field, A. (2009). Discovering Statistics using SPSS (3rd ed.). California: SAGE Publications Inc

Flynn, B. B., Huo, B., \& Zhao, X. (2010). The impact of supply chain integration on performance: A contingency and configuration approach. Journal of Operations Management, 28, 58-71. http://dx.doi.org/10.1016/j.jom.2009.06.001

Frohlich, M. T., \& Westbrook, R. (2001). Arcs of integration: An international study of supply chain strategies. Journal of Operations Management, 19, 185-200. http://dx.doi.org/10.1016/S0272-6963(00)00055-3

Ghana.gov.gh. (n. d.). Ashanti region. Retrieved from http://ghana.gov.gh/index.php/about-ghana/regions/ashanti

Gimenez, C., Vaart, T. V. D, \& Donk, D. P. V. (2012). Supply chain integration and performance: The moderating effect of supply complexity. International Journal of Operations \& Production Management, 32(5), 583-610. http://dx.doi.org/10.1108/01443571211226506 
Hair, J. F. J., Black, C. W., Babin, J. B., \& Anderson, E. R. (2014). Multivariate Data Analysis (7th ed.). Edinburgh Gata, Harlow: Pearson Education Ltd.

Hashemi, A., Butcher, T., \& Chhetri, P. (2013). A modeling framework for the analysis of supply chain complexity using product design and demand characteristics. International Journal of Engineering, Science and Technology, 5(2), 150-164.

Hosseini, M. S., \& Azizi, S. (2012). An investigation on the effect of supply chain integration on competitive capability: An empirical analysis of Iranian food industry. International Journal of Business and Management, 7(5), 73-90. http://dx.doi.org/10.5539/ijbm.v7n5p73

Huang, M. C., Yen, G. F., \& Liu, T. C. (2014). Reexamining supply chain integration and the supplier's performance relationships under uncertainty. Supply Chain Management: An International Journal, 19(1), 64-78. http://dx.doi.org/10.1108/SCM-04-2013-0114

Huo, B. (2012). The impact of supply chain integration on company performance: An organizational capability perspective. Supply Chain Management: An International Journal, 17(6), 596-610. http://dx.doi.org/10.1108/13598541211269210

Huo, B., Qi, Y., Wang, Z., \& Zhao, X. (2014). The impact of supply chain integration on firm performance: The moderating role of competitive strategy. Supply Chain Management: An International Journal, 19(4), 369-384. http://dx.doi.org/10.1108/SCM-03-2013-0096.

Johnson, G., Scholes, K., \& Whittington, R. (2008). Exploring Corporate Strategy (8th ed.). Edinburgh Gate, England: Pearson Education Ltd.

Kim, W. S. (2009). An investigation on the direct and indirect effect of supply chain integration on firm performance. Int. J. Production Economics, 119, 328-346. http://dx.doi.org/10.1016/j.ijpe.2009.03.007

Kotler, P., \& Keller, K. L. (2012). Marketing Management (14th ed.). New Jersey: Pearson Education Ltd.

Lambert, D. M. (2008). An Executive Summary of Supply Chain Management: Processes, Partnerships, Performance. Sarasota, USA: Supply Chain Management Institute.

Leuschner, R., Rogers, D. S., \& Charvet, F. (2012). A meta-analysis of supply chain integration and firm performance. Journal of Supply Chain Management, 49(2), 34-57.

Mackelprang, A. W., Robinson, J. L., Bernardes, E., \& Webb, G. S. (2014). The Relationship between strategic supply chain integration and performance: A meta-analytic evaluation and implications for supply chain management research. Journal of Business Logistics, 35(1), 71-96.

Miguel, L. P. D. S., \& Brito, A. L. L. (2011). Supply chain management measurement and its influence on operational performance. Journal of Operations and Supply Chain Management, 4(2), 56-70.

Moshkdanian, F., \& Molahosseini, A. (2013). Impact of supply chain integration on the performance of Bahman Group. Interdisciplinary Journal of Contemporary Research in Business, 5(1), 184-192.

Näslund, D. (2014). Theoretical perspectives on information sharing in supply chains: A systematic. Supply Chain Management: An International Journal, 19(5/6), 609-625. http://dx.doi.org/10.1108/SCM-12-2013-0460

Näslund, D., \& Williamson, S. (2010). What is management in supply chain management?-A critical review of definitions, frameworks and terminology. Journal of Management Policy and Practice, 11(4), 11-28.

Özdemir, A., \& Aslan, E. (2011). Supply chain integration, competition capability and business performance: A study on Turkish SMES. Asian Journal of Business Management, 3(4), 325-332.

Podsakoff, P. M., MacKenzie, S. B., Jeong-Yeon, L., \& Podsakoff, N. P. (2003). Common method biases in behavioral research: A critical review of the literature and recommended remedies. Journal of Applied Psychology, 88(5), 879-903. http://dx.doi.org/10.1037/0021-9010.88.5.879

Prajogo, D., \& Olhager, J. (2012). Supply chain integration and performance: The effects of long-term relationships, information technology and sharing, and logistics integration. Int. J. Production Economics, 135, 514-522. http://dx.doi.org/10.1016/j.ijpe.2011.09.001 
Rao, S., \& Goldsby, T. J. (2009). Supply chain risks: A review and typology. The International Journal of Logistics Management, 20(1), 97-123. http://dx.doi.org/10.1108/09574090910954864

Schoenherr, T., \& Swink, M. (2012). Revisiting the arcs of integration: Cross-validations and extensions. Journal of Operations Management, 30(1/2), 99-115. http://dx.doi.org/10.1016/j.jom.2011.09.001

Seo, Y. J., Dinwoodie, J., \& Kwak, D. W. (2014). The Impact of innovativeness on supply chain performance: Is supply chain integration a missing link? Supply Chain Management: An International Journal, 19(5/6), 733-746. http://dx.doi.org/10.1108/SCM-02-2014-0058

Sezen, B. (2008). Relative effects of design, integration and information sharing on supply chain performance. Supply Chain Management: An International Journal, 13(3), 233-240. http://dx.doi.org/10.1108/13598540810871271

Stonebraker, P. W., \& Liao, J. (2006). Supply chain integration: Exploring product and environmental contingencies. Supply Chain Management: An International Journal, 11(1), 34-43. http://dx.doi.org/10.1108/13598540610642457

Tabachnick, G. B., \& Fidell, S. L. (2013). Using Multivariate Statistics (6th ed.). New Jersey: Pearson Education Inc.

Tang, C. S. (2006). Robust strategies for mitigating supply chain disruptions. International Journal of Logistics Research and Applications: A Leading Journal of Supply Chain Management, 9(1), 33-45. http://doi:10.1080/13675560500405584

Vaart, T. V. D., \& Donk, D. P. V. (2008). A critical review of survey-based research in supply chain integration. Int. J. of Production Economics, 111, 42-55. http://dx.doi.org/10.1016/j.ijpe.2006.10.011

Vickery, S. K., Jayaram, J., Droge, C., \& Calantone, R. (2003). The Effects of an integrative supply chain strategy on customer service and financial performance: An analysis of direct versus indirect relationships. Journal of Operations Management, 21, 523-539. http://dx.doi.org/10.1016/j.jom.2003.02.002

Westbrook, T. J. (2002). Integrating the supply chain. Washington: World Wide Wood Network Ltd.

Wong, Y. C., Boon-itt, S., \& Wong, W. Y. C. (2011). The contingency effects of environmental uncertainty on the relationship between supply chain integration and operational performance. Journal of Operations Management, 29, 604-615. http://dx.doi.org/10.1016/j.jom.2011.01.003

Yan, Y., Zhang, H. S., \& Zeng, F. (2010). The exploitation of an international firm's relational capabilities: An $\begin{array}{llllll}\text { empirical study. Journal of Strategic Marketing, 18(6), 473-487. } & \text {. }\end{array}$ http://dx.doi.org/10.1080/0965254X.2010.525251

Zheng, Y., Liu, J., \& George, G. (2010). The dynamic impact of innovative capability and inter-firm network on firm valuation: A longitudinal study of biotechnology start-ups. Journal of Business Venturing, 25, 593-609. http://dx.doi.org/10.1016/j.jbusvent.2009.02.001

\section{Appendix}

Empirical contributions on the relationships between supply chain integration, value creation, and financial performance

\begin{tabular}{|c|c|c|c|c|}
\hline Author(s) & Empirical setting/methodology & Focal learning construct(s) & Performance variables & Key findings \\
\hline $\begin{array}{l}\text { Huo et al. } \\
(2014)^{\circ}\end{array}$ & $\begin{array}{l}\text { China. Data collected from } 604 \\
\text { manufacturers } \\
\text { questionnaires. } \\
\text { regression analysis was usedr }\end{array}$ & $\begin{array}{ll}\text { 1. SCI: } & \text { Internal } \\
\text { integration }(\mathrm{II})^{1}, & \text { Process } \\
\text { integration }(\mathrm{PrsI})^{1} \text {, } & \text { Product } \\
\text { integration }(\mathrm{PtI})^{1} & \\
2 . \quad \text { Competitive } & \text { strategy } \\
(\mathrm{CS})^{2} & \end{array}$ & $\begin{array}{l}\text { 1.Operational } \\
\text { performance (OP) } \\
\text { 2. Financial performance } \\
\text { (FP) }\end{array}$ & $\begin{array}{l}\text { 1. Only II and PrsI } \\
\text { sig. relate to OP } \\
\text { positively } \\
2 . \quad \text { Only II and PtI } \\
\text { sig. affect financial } \\
\text { performance positively. } \\
\text { 3. CS does not sig. } \\
\text { moderate SCI } \rightarrow \text { OP } \\
\text { link }\end{array}$ \\
\hline
\end{tabular}




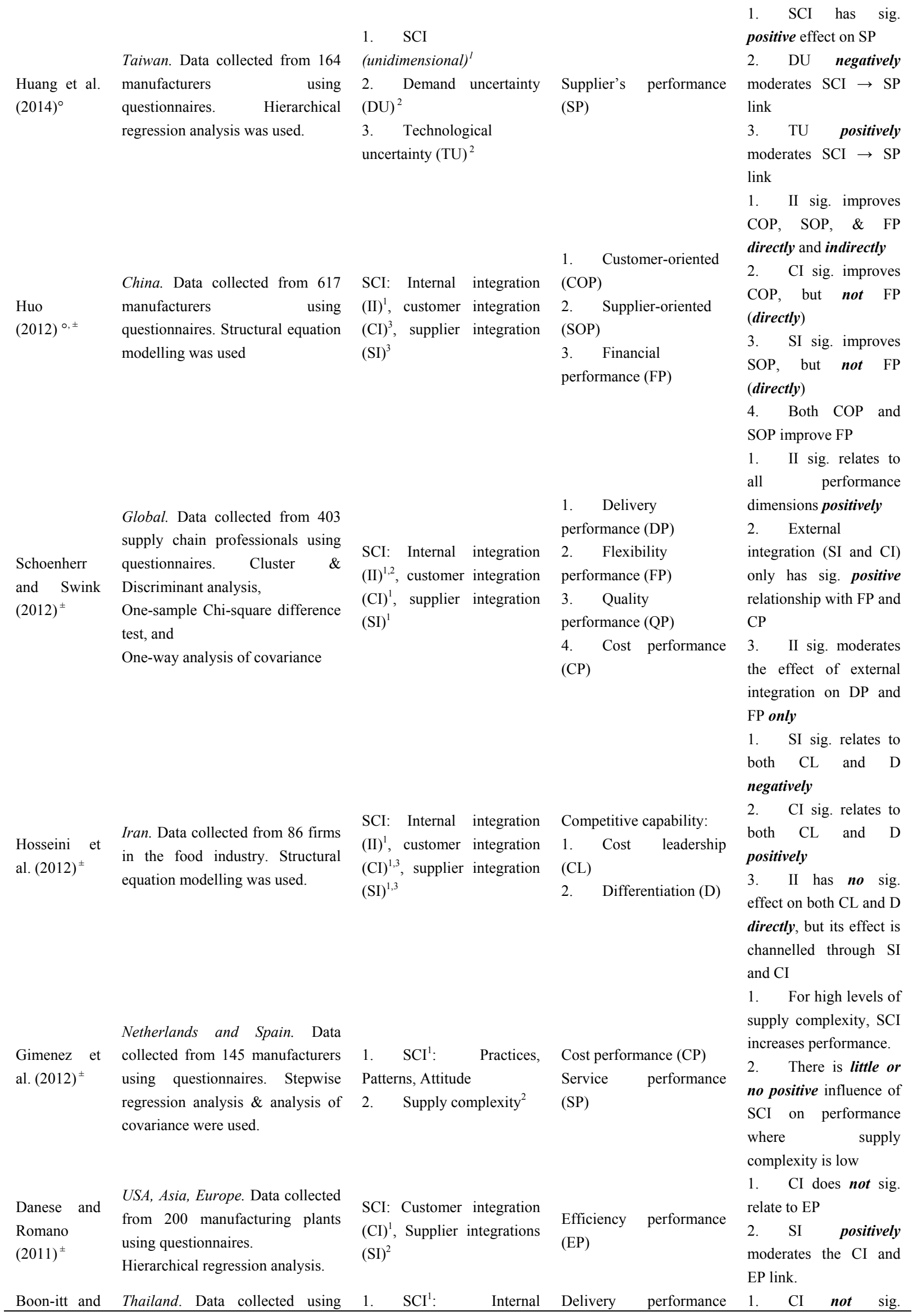




\begin{tabular}{|c|c|c|c|}
\hline \multirow{6}{*}{$\begin{array}{l}\text { Wong (2011) } \\
\pm\end{array}$} & \multirow{6}{*}{$\begin{array}{l}\text { questionnaires from } 1511^{\text {st }} \text { tier } \\
\text { suppliers in automotive industry. } \\
\text { Hierarchical regression analysis } \\
\text { was used. }\end{array}$} & integration (II), Supplier (DP) & related to DP \\
\hline & & integration (SI), Customer & 2. Both II and SI are \\
\hline & & integration $(\mathrm{CI})$ & sig. related to DP \\
\hline & & 2. Demand uncertainty & positively \\
\hline & & $(\mathrm{DU})^{2}$ & 3. Both DU and TU \\
\hline & & $\begin{array}{l}\text { 3. Technological } \\
\text { uncertainty }(\mathrm{TU})^{2}\end{array}$ & $\begin{array}{l}\text { sig. moderate } \mathrm{II} \rightarrow \mathrm{DP} \\
\text { and } \mathrm{SI} \rightarrow \mathrm{DP} \text { links }\end{array}$ \\
\hline
\end{tabular}

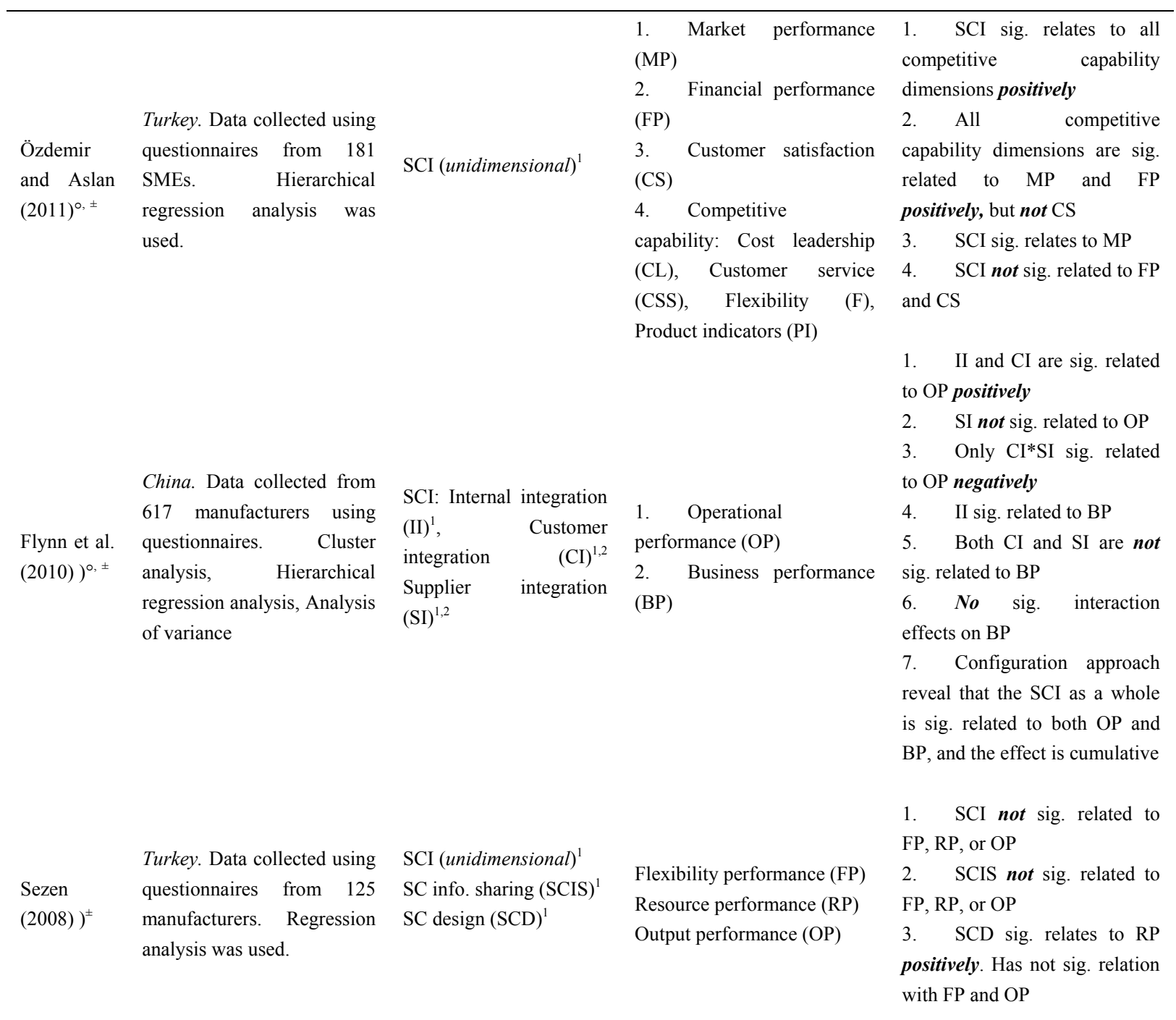

Notes. ${ }^{1}$ Predictor variable; ${ }^{2}$ Moderating variable; ${ }^{3}$ Mediating variable; ${ }^{\circ}$ had at least an item measuring financial performance as operationalized in this study; ${ }^{ \pm}$had at least an item measuring value creation as operationalized in this study.

\section{Copyrights}

Copyright for this article is retained by the author(s), with first publication rights granted to the journal.

This is an open-access article distributed under the terms and conditions of the Creative Commons Attribution license (http://creativecommons.org/licenses/by/3.0/). 